\title{
Cinsel Suçlara Yönelen Çocuk Failler: Cinsel Suçların Dinamikleri
}

\author{
Juvenile Sexual Offenders: Dynamics of the Sexual Offenses \\ ๑ Sunay Frrat ${ }^{1}, \oplus$ Mehmet Aykut Erk ${ }^{1}$ \\ 1Çukurova Üniversitesi, Adana, Türkiye
}

Cinsel eylemi bireye yönelten fail için; suçun işlenişi, failin kişilik özellikleri, failde mevcut ruhsal bozukluklar, suçun tekerrürü ve mağdurun özellikleri bakımından farklı tanımlamalar yapılabilmektedir. Bu çalışma cinsel suçların faili konumunda bulunan ve suça sürüklendiği düşünülen ergenlerin risk faktörlerini ve kişilik özelliklerini belirlemeyi, suçun işlenişi ya da suç öyküsü sınıflandırmalarının nasıl oluşturulduğunu incelemeyi, suç ve davranış bilimlerine, penolojik müdahalelere ve rehabilitasyon girişimlerine farklı bir bakış açısı oluşturarak katkı sağlamayı amaçlamaktadır. Adli olguların sonuçlarına göre cinsel saldırı failleri çoğunlukla heterojen bir grup olarak nitelendirilmektedir. Dolayısıyla faillerin belirli özelliklerine göre homojen gruplara indirgenmesinin, adalet mekanizmasının doğru bir şekilde işleyebilmesi adına yargı sürecine kolaylık sağlayacağı düşünülmektedir.

Anahtar Sözcükler: Cinsel saldırı, cinsel istismar, cinsel suçlara yönelen çocuklar, risk faktörleri, fail tipolojisi

For the perpetrator who directs the sexual act to the individual; different definitions can be made in terms of the modus operandi, the personality characteristics, the mental disorders, the repetition of the crime and the characteristics of the victim. This study aims to determine the risk factors and personality traits of adolescents who are perpetrators of sexual crimes and who are thought to be driven to crime, to examine how crime is committed or how crime history classifications are created, and to contribute to crime and behavioral sciences, penological interventions and rehabilitation initiatives by creating a different perspective. According to the results of the cases, perpetrators of sexual assault are mostly characterized as a heterogeneous group. Therefore, it is thought that reducing the perpetrators into homogeneous groups regarding their specific characteristics will facilitate the judicial process in order for the justice mechanism to function correctly.

Keywords: Sexual assault, sexual abuse, juvenile sex offenders, risk factors, offender typology

\section{Giriş}

Dünya Sağlık Örgütü’nün geniş çaplı tanımına göre cinsel şiddet; ev ve iş ortamı dahil olmak üzere mağdur ile ilişkisinden (yakınlık derecesinden, bağından) bağımsız olmak kaydıyla herhangi bir kişi tarafından bireyin beden bütünlüğüne yönelik dolaylı ya da direkt olarak her türlü şiddet ve zorlama yöntemi kullanarak yapılan, cinsel eylem teşebbüsü, gerçekleştirilmiş cinsel saldırı, mağdur tarafindan istenmeyen cinsel içerikli yorumlar ve hakaretlerdir (WHO 2002, 2011). Cinsel şiddet tanımına bağlı olarak cinsel saldırı ise, mağdurun vücut dokunulmazlığının ihlal edildiği bir suç tipidir. Bu ifadeden hareketle failin mağdurun vücut dokunulmazlığına kastedecek bir biçimde yönelttiği her eylem cinsel saldırı sınıfına girebilmektedir (TCK 2004).
Cinsel istismar ise; çocuğun cinsel stimülasyon ve tatmin amacıyla bir yetişkin tarafından kullanılması, fuhuşa zorlanması ve pornografi vb. suçlar açısından cinsel bir meta olarak kullanılması şeklinde tanımlanmaktadır (Nurcombe 2000, Polat 2000). Cinsel istismar; çocuğa yöneltilen teşhircilik, pornografi ya da genital bölgeye dokunma veya vücut boşluklarına organ ya da sair bir cismin sokulmasıyla tanımlı çok geniş bir yelpazeye sahiptir (Polat 2000, Polat 2017).

Cinsel nitelikli suç olan eylemlere maruz kalanların kim olduğuna göre de mağdur profili değişmektedir. Cinsel istismar, psikoseksüel gelişimi tamamlanmamış ve küçük yaşta sayılan bir çocuğun ya da ergenin cinsel eylemlere maruz kalmasını ifade ederken, cinsel saldırıda mağdurun

$18^{\text {th }}$ International Eastern Mediterranean Family Medicine Congress (DAAHK 2019), 25-28 April, 2019'da sözel bildiri olarak sunulmuştur.

Yazışma Adresi/Address for Correspondence: Sunay Fırat, Çukurova Üniversitesi, Bağımlılık ve Adli Bilimler Enstitüsü, Adli Bilimler Anabilim Dalı, Adana, Türkiye

E-posta/E-mail: sunayfirat@gmail.com Geliş tarihi/Received: 14.06.2021 Kabul tarihi/Accepted: 03.08.2021

ORCID ID: 0000-0002-9960-0836 
psiko-seksüel gelişimini tamamlamış olduğu düşünülür (Burt ve Estep 1981, Polat 2017). Yapılan çalışmalara göre erken yaşta cinsel istismara maruz kalmış bireylerde, ileriki yaşlarda cinsel saldırıya uğramış bireylere göre psikolojik, gelişimsel ve sosyal boyutlarda farklı sorunlara rastlanılmıştır (Kara ve ark. 2004, Kurtay ve ark. 2004, Taner ve Bahar 2004). Yine literatüre göre cinsel istismara uğramış erkek bireylerin de ilerleyen yaşlarda istismarcı olma riski taşıdığı bilinmektedir (Kaseweter ve ark. 2016, Hunter 2017, Ueda 2017). Benzer bir ayrım herhangi bir cinsel eylemi bir bireye karşı yönelten fail için de söz konusu olmaktadır. Suçun işlenişi, failin kişilik özellikleri, failde mevcut ruhsal rahatsızlıklar, suçun tekerrürü ve mağdurun özellikleri bakımından fail için farkh tanımlamalar yapilabilmektedir (Connell 2000, Fe Koch 2004, Easton ve ark. 2013, Ueda 2017). Türk Ceza Kanunu'nda (TCK) 2014 yllında 6545 sayılı kanunla yapılan değişiklikle birlikte cinsel istismar suçu, nitelikli halleriyle beraber istismarın tanımı açısından genişletilmiştir. Böylelikle hukuki anlamda da failin istismarcı olarak nitelendirilmesi sağlanmıştır. Cinsel saldırı faili ise istismarcıdan farklı olarak cinsel eylemin gerçekleştirildiği mağdurun yaşına göre tanımlandırılmıştır (TCK 2014).

Adli olguların sonuçlarına göre cinsel saldırı failleri heterojen bir grup olarak nitelendirilmektedir (Gannon ve ark. 2012, Vess ve Skelton 2010). Öte yandan faillerin belirli özelliklere göre homojen gruplara indirgenmesi, adalet mekanizmasının doğru bir şekilde işleyebilmesi adına kolaylık sağlamaktadır (MartínezCatena ve ark. 2017). Failler, cinsel nitelikte eylemin yöneltildiği mağdurun özelliklerine, eylemin gerçekleştirildiği bağlama, eylemin ortaya nasıl konulduğu ve failin kişilik özelliklerine göre farkl gruplarda incelenebilinmektedir (Woodworth ve ark. 2013). Faillerin temel karakteristikleri ve davranışlarını etkileyen risk faktörleri, suçun yapısı açısından söz konusu olmaktadır. Risk faktörleri statik (durağan) ve dinamik (değişken) olmak koşuluyla ikiye ayrılmaktadır. Bu ayrıma göre statik faktörler; çevreden herhangi bir müdahale olsun veya olmasın değişmesi zor etkenler iken (köken aile, mental retardasyon, yaş vb.), dinamik faktörler, uygun müdahale yöntemleriyle olumlu yönde değişebilen etmenlerdir (Harkins ve Beech 2007, Whitaker ve ark. 2008, Abbey ve ark. 2011).

Statik risk faktörleri açısından bakıldığında yaş, faillerin sınıflandırılmasında kritik bir önem taşımaktadır. Bu bağlamda çocuk cinsel suçlular, cinsel saldırı ve cinsel istismar failleri arasında önemli bir bölümü oluşturmaktadır (Joyal ve ark. 2016). Genellikle 12 yaş ile başlayıp 18 yaştan küçük olmak kaydıyla cinsel eylemin faili olan Cinsel Suçlara Yönelen Çocuk (CSYÇ), bu gruba özel değerlendirmeler ve tedavi programlarıyla suçun tekerrürü ve olası cinsel işlev bozuklukları bakımından diğer cinsel suçlulardan ayrılmaktadır (Worling ve Curwen 2000, Fanniff ve Becker 2006, Reitzel ve Carbonell 2006).

Cinsel saldırı ve cinsel istismar suçlarına ilişkin penolojik yaklaşımlar; failin cezasının nasıl infaz edileceği ve suç içeren düşünce ve davranış örüntülerinin yeniden şekillendirilmesi, varsa ruhsal bozuklukların sağaltımı gibi konularla ilgilenmektedir (Farmer ve ark. 2016). Ancak CSYÇ’lerin de günümüzde detaylı incelenmesi sonucu yetişkin gruplardan risk faktörleri ve fail tipolojisi yönünden ayrıldığı anlaşılmaktadır.

$\mathrm{Bu}$ çalı̧̧manın amacı cinsel istismarın veya cinsel saldırının faili konumunda bulunan ergen faillerin risk faktörlerini, gelişim öykülerinde bulunan olası ruhsal bozuklukların ve/ veya kişilik özelliklerini belirlemek ve suçun işlenişi ya da suç öyküsü bazlı tipolojilerin nasıl oluşturulduğunu literatür temelli incelemek suç ve davranış bilimlerine, penolojik müdahalelere ve rehabilitasyon girişimlerine farklı bir bakış açısı oluşturarak katkı sağlayabilmektir.

\section{Cinsel Suçlara Yönelen Çocuklar (CSYÇ)}

Cinsel suçlara yönelen çocuk olgular, ilk bakışta heterojen gibi görünse de birtakım özelliklere göre bazı ortak noktalarda birleşebilen homojen gruplar yardımıyla incelenmektedir. CSYÇ'ler arasından alt grupların belirlenebilmesi, cinsel suçların etiyolojisi açısından önemli olduğu kadar erken yaşta suçlu pozisyonuna düşen çocuk ve ergenlerin rehabilitasyonu ve sağaltımları için de gerekmektedir. Yapılan çalışmalara göre iki temel CSYÇ sınıflandırılması belirlenmiştir. Bunlardan ilki failin suç öyküsüne göre nitelendirilirken, diğeri failin eylemi yönelttiği mağdurun yaşına göre oluşturulmaktadır (Butler ve Seto 2002, van Wijk ve ark. 2007). CSYÇ’ler cinsel eylemi yönelttikleri mağdurun yaşına göre kategorize edildiklerinde; ergenlik öncesi dönemlerdeki çocukları mağdur olarak seçen grup ve kendi yaş grubundaki akranlarına ve yetişkinlere yönelik cinsel eylemde bulunanlar şeklinde iki alt gruba ayrilmaktadır (Seto ve Lalumière 2010, Keelan ve Fremouw 2013).

Kendilerinden daha küçük yaş grubundaki çocuklara cinsel eylemi yönelten suçlulara yine cinsel istismarcı adı verilirken, kendi akranlarına yönelttikleri cinsel eylemlerden ötürü ise bu suçlu grubu, akran istismarcısı (peer abuser) adını almaktadır. Yapılan çalışmalara göre bu iki grup davranış problemleri ve sosyoekonomik etkenler açısından farklllıklar göstermektedir (Aebi ve ark. 2012, Leroux ve ark. 2016).

Kurbanlarının yaş aralığına göre ayrılan bu iki grubun, risk faktörleri açısından da farklılaştığı görülmektedir. Literatürde risk faktörleri; bireysel ve çevresel başlıkları altında incelenmektedir. Bireysel risk faktörleri; ruh sağlığı, psikososyal özellikler, kişilik özellikleri ve bilişsel yetenekler olarak dört alt başlığa ayrılmaktadır. Araştırmacılar, bu kategorileşme yöntemi ile kendinden küçük çocuklara cinsel istismarda bulunanlar ya da akran istismarcısı çocuklar arasında daha açıklayıcı bir yaklaşıma başvurmaktadırlar.

\section{Bireysel Risk Faktörleri}

Psikososyal özellik değişkenleri arasında düşük özgüven, disfori ve sosyal izolasyon bulunmaktadır (Ueda 2017). Yapılan çalışmalarda, iki grubun karşılaştırıldığı disfori de dahil olmak üzere benlik saygısı ve sosyal izolasyon gibi psikososyal fonksiyonlar, kendinden küçük çocuklara cinsel istismarda bulunan çocuklarda, akran istismarcılarına göre daha düşük bulunmaktadır (Hunter ve ark. 2003). Benzer olarak Hendriks 
ve Bijleveld (2004) ve van Wijk ve ark. (2006) yaptıkları araştırma bulgularına göre kendinden küçük çocuklara yönelik cinsel istismara yönelen çocukların nörotizm bakımından daha yüksek puanlar aldıkları tespit edilmiştir. CSYÇ’lerde sosyal izolasyon boyutu tıpkı yetişkin cinsel istismarcılarda olduğu gibi yüksek oranda suçu öngörücü bir faktördür. Erken yaşlarda sosyal izolasyona maruz kalmak da olağan dışı cinsel uğraşları ve dürtüselliği artırabilmektedir. Benlik saygısının, kendinden küçük çocuklara yönelik cinsel istismara yönelen çocuklarda akran istismarcısı çocuklara göre daha düşük bulunmuştur (Gunby ve Woodhams 2010).

Ruh sağlığı açısından CSYÇ’lerin daha önce tanısı konulmuş bütün psikiyatrik bozuklukları incelenmektedir. Ruhsal bozukluklar gelişimsel ve çevresel faktörlerin etkisiyle oluşmakta ve suçun ortaya çıkmasında diğer risk faktörleriyle etkileşmektedir (Ueda 2017). Bu bakımdan ruhsal bozukluklar, suçun hem sebebi hem de suçun çıktılarına göre sonucu olabilmektedir.

Literatürdeki birçok çalışmaya göre, adli çocuk olgularda en az bir psikiyatrik tanının bulunma sıklığı $\% 70$ ile \%90 arasındadır (Fazel ve ark. 2008, Colins ve ark. 2009). Ruhsal bozuklukların oluşumuna sebep olan etkenlerden biri de çocukluk çağı travmalarıdır (Stewart ve ark. 2004, Carr ve ark. 2013, MacMillan ve ark. 2013). Fiziksel istismar ve duygusal istismar gibi yaşantılar çocuğun Travma Sonrası Stres Bozukluğu, depresyon, madde kullanım bozukluğu ve suça yönelmesine neden olabilecek dışa yönelim bozuklukları geliştirmesine sebep olabilmektedir. Özellikle duygusal istismarın, sanılanın aksine kaygı, depresyon, psikosomatik bozukluklar, kişilik bozukluklarına zemin hazırladığı ve psikoz gelişimine en az fiziksel istismar kadar katkısı bulunduğu düşünülmektedir (Spertus ve ark. 2003).

CSYÇ’ler arasındaki ruhsal durumu karşılaştıran bir çalı̧̧maya göre istatistiksel olarak anlamlı bir fark bulunamamıştır (Glowacz ve Born 2013). Ancak kendinden daha küçük çocuklara cinsel istismarda bulunan çocuklarda akran istismarcılarına kıyasla daha fazla (\%55-\%33) psikopatolojik bulgular elde edilmiştir (Hendriks ve Bijleveld 2004). Kendinden daha küçük çocuklara cinsel istismarda bulunan çocuklarda özellikle klinik depresyon bulguları ve kaygı oranları daha yüksek iken akran istismarcısı çocukların madde kullanım bozuklukları bakımından diğer gruba oranla daha yüksek eştanıya sahip oldukları tespit edilmiştir. Ancak yapılan diğer çalışmalar, kendinden daha küçük çocuklara cinsel istismarda bulunan çocukların yüksek oranlarda madde kullanımına işaret etmektedir. Yüksek anksiyeteye sahip ergenin, madde kullanımına yönelmesi bir başa çıkma stratejisi olarak düşünülmektedir (Comeau ve ark. 2001).

CSYÇ'lerin alt gruplara ayrilmasında rol oynayan mevcut risk faktörleri ve alt grubu oluşturan etmenler, CSYÇ'lerin eylemi yönelteceği mağduru seçiminden, eylemin ortaya konulmasına kadar geniş bir yelpazede etki göstermektedir. Risk faktörleri bakımından da yetişkin faillerden ayrılmaktadırlar. Özellikle kişiliği oluşturan öncüllerin ergenlik çağında ortaya çıktığı düşünüldüğünde yetişkinlerde tespit edilebilen kişilik bozuklukları çocuklarda davranış düzeyinde kalmaktadır.
$\mathrm{Bu}$ bakımdan yetişkinlere ait risk faktörleri ve tipolojilerin incelenmesi çocukluk çağındaki antisosyal davranış öncüllerinin yordayıcılığını ortaya koymaktadır.

Kişilik özellikleri alt boyutu ise antisosyal davranışlar, tanısı konulmamış içe yönelim ve dışa yönelim bozuklukları gibi daha çok davranışsal sorun olan özellikleri nitelendirmektedir. Antisosyal kişilik kalıbının çocukluktaki yordayıcısı olarak Karşıt Olma- Karşı Gelme Bozukluğu ve Davranım Bozukluğu da kişilik özellikleri boyutunda incelenmektedir. Karşıt Olma-Karşı Gelme Bozukluğu çocuğun en az altı aylık bir periyotta öfke, irritabl duygudurum ya da karşı gelici davranışlar göstermesiyle tanılanan bir bozukluktur (American Psychiatric Association 2013). Davranım Bozukluğu ise Karşıt Olma-Karşı Gelme Bozukluğuna benzer karakteristiklere sahiptir ancak sosyal normlara uymama gibi ayırıcı davranış örüntüleriyle farklılaşmaktadır. Davranım bozukluğu, Ruhsal Bozuklukların Tanısal ve İstatistiksel El Kitabı'na (DSM-5) göre ruhsal bozukluklar siniflamasına girmesine rağmen, bu tanıyı almış her çocuk ilerleyen yaşlarında antisosyal kişilik bozukluğu göstermemektedir (American Psychiatric Association 2013). Öte yandan ergenlere kişiliğin hala gelişimini tamamlamadığ düşüncesiyle antisosyal kişilik bozukluğu tanısı konulması doğru bulunmamaktadır. Ayrıca risk faktörleri incelenirken daha çok davranış belirtileri öne çımaktadır (Adshead ve ark. 2012).

Dikkat Eksikliği-Hiperaktivite Bozukluğuna ilişkin belirtiler ise özellikle sosyal bağlamda ebeveynlere ve çevreye yönelik ortaya çıkan problemler gerekçesiyle dışa yönelim bozukluğu gibi ele alınmaktadır (American Psychiatric Association 2013). Bunlara ek olarak, olağandışı cinsel uğraşlar ise yine kişilik alt boyutunda incelenmektedir. Kişilik özellikleri, bireylerin duygu, düşünce ve davranışlarını yansıtma biçimlerine göre CSYÇ’ler arasında farkllılk göstermektedir.

Yapılan çalışmalara göre kendinden küçük çocuklara yönelik cinsel istismarda bulunan çocuklar, yaşadıkları sorunlara tepki olarak daha itaatkâr ve konformist bir yaklaşım sergilerken, akran istismarcısı çocukların ise, yüksek oranlarda davranım bozukluğu tanısı almakla birlikte daha antisosyal ve dişa vurumsal tepkiler gösterdikleri tespit edilmiştir (van der Put ve Asscher 2015, Joyal ve ark. 2016). Aebi ve ark. (2012) çalışmasına göre ise kendinden küçük çocuklara yönelik cinsel istismarda bulunan çocuklar, akran istismarcısı çocuklara kıyaslandığında nispeten daha düşük agresif davranış sergiledikleri belirlenmiştir.

Antisosyal davranış, dar anlamda bilinçli olarak başkalarına ve eşyalara zarar verme olarak tanımlanmaktadır. Gelişimcilere göre antisosyal davranış genel bir kalıba sokulamamaktadır. $\mathrm{Bu}$ açıdan antisosyal davranış örüntüleri; otorite ile zıtlaşma (authority conflict) boyutu, gizil (covert) boyut, aleni (overt) boyut ve pervasız (reckless) boyut olmak üzere 4 farklı alt boyutta incelenmektedir (LeBlanc ve Loeber 1998). Otorite ile zıtlaşma boyutunda; inatçı olma, karşı gelen tavırlar ve ev, okul ve sosyal ortamlardaki otorite figürlerine karşı asi tutum göze çarpmaktadır. Gizil boyut ise, antisosyal davranışın aleni boyutunun aksine daha örtük bir şekilde gerçekleşmektedir. Aldatma, sahtekarlık ve sıklıkla yalan söyleme bu davranış 
şeklini açıklamaktadır. Aleni boyut, dışarıdan rahatlıkla gözlenebilen bir yapıda gerçekleşmektedir. Fiziksel saldırganlık ve şiddet en önemli göstergeleri olmaktadır. Korunmasız cinsel ilişki, tehlikeli davranışları ders almaksızın tekrar etme, sürekli heyecan arayışında olma gibi yineleyici tehditkâr davranışlar ise pervasız boyutu tanımlamaktadır (LeBlanc ve Loeber 1998). LeBlanc ve Loeber'in (1998) çalışmasına göre alt boyutta görülen bu davranışların birçoğu dönemsel olarak bireyler tarafından sergilenmektedir. İnatçılık, ısırmak, tekmelemek, küfürlü konuşmak gibi davranışlardan en az biri erken yaş dönemlerinde \%90 oranında ortaya çıkmaktadır. Ancak büyüme çağındaki çocukların sadece bir kısmı otorite ile zıtlaşma, gizil boyut, aleni boyut ve pervasız davranışların hepsini bir arada göstermektedir. Öte yandan otorite ile zıtlaşma davranışının 12 yaşından önce görülmesi, antisosyal davranışın yerleşmesi adına bir risk olarak değerlendirilmektedir. Ancak ergenlikle beraber bu karşı gelici davranışların da normal gelişimin bir gereği olduğu vurgulanmaktadır (Moffitt 1993).

Loeber ve arkadaşlarının (1994) üçayaklı teorik modeline göre ise, otorite ile zıtlaşma, gizil boyut ve aleni boyut piramit şeklinde oluşturulmuş modelin üçayağını temsil etmektedir. Bu modele göre bu üçayaklı gelişimi gösteren bireyler genellikle otorite ile zıtlaşmaya başlayıp daha sonrasında gizil ve aleni antisosyal davranışlar göstermektedirler. Özellikle bu üç davranış tipini de beraber gösteren CSYÇ'lerin daha sık ve daha şiddet içerikli suçlara bulaştıkları tespit edilmiştir (Howell ve ark. 1995, Loeber ve ark. 2001).

Adli çocuk olgular, gizil ve aleni boyuta ilişkin davranışlarına göre ayırt edilebilmektedir. Fakat herhangi bir boyutla betimlenen davranış örüntülerine sahip adli çocuk olgular sadece bir boyuta ait davranışlar sergilememektedir. Loeber ve arkadaşlarına (1993) göre niteliği bakımından farklı birden fazla davranış örüntüsüne sahip adli çocuk olgular, birden fazla davranış örüntüsü göstermeyen diğer çocuklara göre daha sıklıkla suça karışmaktadırlar. Yine aynı çalışmada tartışıldığı üzere gizil ve aleni boyutlarda antisosyal davranışlar gösteren gruplar, düşük antisosyal özellikler gösteren gruba kıyasla daha erken yaşta suça karışmaktadırlar. Gizil ve aleni boyutlarda antisosyal davranışlar gösteren adli çocuk olgular sıklığı ve şiddeti artan bir biçimde suç işlemektedirler. Aile boyutu göz önünde bulundurulduğunda gizil ve aleni antisosyal davranış örüntülerine sahip grupta incelenen adli çocuk olgularda, düşük antisosyal gruba kıyasla aile üyelerinde daha fazla suç öyküsü, alkol ve madde kullanımı ve ruhsal bozukluk tespit edilmiştir. Yapılan örtük sınıf analizi çalışmalarına göre gizil ve aleni antisosyal davranış örüntülerine sahip grupların her ikisinin de işledikleri cinsel suçların sıklığının ve şiddetinin zamanla artış gösterdiği bulunmuştur (Butler ve Seto 2002, McCuish ve ark. 2015). Örneğin aleni grupta görülen cinsel suçlar giderek artan agresyonun ve şiddet davranışının bir göstergesi olabilmekte, aleni grupta incelenen CSYÇ'ler dirençle karşılaştıklarında şiddete başvurabilmektedirler. Aleni grupta incelenen CSYÇ'lerin istediklerini elde etme konusunda zorbalık davranışında bulunma olasılıkları daha yüksek bulunmuş ve diğerlerinden ayırt edici olarak baskı altına alma doğalarından dolayı suçu yönelttiği mağdura daha önceden de zorbalık davranışında bulunma olasılığının daha yüksek olduğu tespit edilmiştir (McCuish ve ark. 2015).

Gizil grupta incelenen CSYÇ'ler ise cinsel eylemleri iyi gizlenmiş ve aldatıcı bir yol izlemektedir. Bu davranış biçimi, yapılan çalışmada çoğunlukla cinsel eylem gerçekleştikten sonra suçu bildiremeyecek düzeydeki bir mağdurun (zihinsel engelli çocuklar ya da cinsellik hakkında farkındalığı olmayan küçük çocuklar vb.) seçilmesinde aktif rol oynamakta ve seçilen hedef grubun kendini savunamayacak derecede davranışlarını değerlendirme yetisi azalmış bireyler olduğu belirlenmiştir (McCuish ve ark. 2015). Gizil grupta incelenen CSYÇ'ler kişisel tercihlerine göre hareket etmekten çok fırsatları kovalayan bir yapıya sahip oldukları ve suç içeren eylemlerini sıklıkla fırsatçı bir biçimde ortaya koydukları belirlenmiştir (Ford ve Linney 1995, Seto ve Lalumière 2010).

Atipik veya olağan dışı cinsel uğraşlar bakımından ise iki grup arasında anlamlı bir fark görülmemektedir. Ancak kendinden daha küçük çocuklara cinsel istismarda bulunan çocukların, akran istismarcısı çocuklara göre daha yüksek oranda (\%57,7$\% 41,3$ ) tuhaf seksüel fantezileri olduğu tespit edilmiştir (Joyal ve ark. 2016). Bilişsel yetenekler, CSYÇ’lerin entelektüel fonksiyonlarına bağlı olarak zekâ testlerinden aldıkları puanlara göre nitelendirilmektedir. Kendinden daha küçük çocuklara cinsel istismarda bulunan çocuklar ile akran istismarcısı çocuklar arasında yapılan karşılaştırma çalışmalarına göre IQ seviyelerinde anlamlı bir farklılık bulunamamıştır (Hsu ve Starzynski 1990). Ancak bu kanının aksine van Wijk ve arkadaşlarının (2005) çalı̧masına göre kendinden daha küçük çocuklara cinsel istismarda bulunan çocukların, diğer gruba kıyasla Raven Matriks Zekâ Testinden görece daha yüksek $(126,63$ - 108,60) puanlar aldıkları belirlenmiştir.

\section{Çevresel Risk Faktörleri}

Aile alt boyutu ise tekrar kendi içinde çocukluk çağı öyküsü ve aile karakteristikleri olarak iki gruba ayrilmaktadır. Çocukluk çağı öyküsünde odak CSYÇ'lerin yaşamış olduğu cinsel istismar öyküleri olmaktadır. Yapılan çalışmalara göre yaşanan cinsel istismar olgularında faillerin hiç karşılaşılmayan bir yabancı olma oranı \%20'den daha azdır (Finkelhor 2009). Bu açıdan cinsel istismar öyküsünün aile alt boyutunda ele alınması gerekmektedir. Aile karakteristikleri ise ailenin geliri, ebeveyn etkililiği, ailede suç öyküsü ve aile içi şiddete tanık olma gibi değişkenler olduğu belirlenmiştir (Ueda 2017).

Aile içi yapıları ve ailenin işlevi bakımından, kendinden daha küçük çocuklara cinsel istismarda bulunan çocuklar ile akran istismarcısı çocuklar arasında birtakım farklllıklar bulunmaktadır. Gunby ve Woodhams'ın (2010) çalışmasına göre, kendinden daha küçük çocuklara cinsel istismarda bulunan çocuklar daha bozuk aile yapılarında yetişmekteyken, akran istismarcısı çocuklar denetimin daha az ve sınırların daha belirsiz olduğu aile yapılarında büyümektedirler. Buna ilave olarak, akran istismarcılarının aile üyeleri arasında, akran istismarcısı çocukların aile üyelerine oranla daha fazla suç öyküsü bulunduğu belirlenmiştir. Düşük gelir düzeyi ve aile içi şiddet ise iki grup için 
de benzer düzeyde risk faktörleridir. Ancak Fanniff ve Becker'in (2006) çalışmasına göre, kendinden daha küçük çocuklara cinsel istismarda bulunan çocukların daha fazla aile içi şiddete tanık olduğu tespit edilmiştir.

Arkadaş çevresi boyutundaki risk faktörleri ise zorbalığa maruz kalma, akran ilişkileri ve suç öyküsü bulunan diğer akranlarla arkadaşlık boyutu bakımından incelenmektedir. Akran istismarcısı çocuklar, kendinden daha küçük çocuklara cinsel istismarda bulunan çocuklara göre kişilik özelliklerinin daha impulsif olması bakımından ayrılmaktadırlar (Leroux ve ark. 2016). Yapılan çalışmalara göre, adli çocuk olguların arkadaşlık ilişkilerini de kendilerine benzer bireylerle sürdürdükleri tespit edilmiştir. $\mathrm{Bu}$ açıdan bakıldığında akran istismarcıları, suç öyküsü bulunan akranlarıyla ilişkiler kurabilmekte ve onlarla beraber suç içeren eylemler gerçekleştirebilmektedirler (Joyal ve ark. 2016). Kendinden daha küçük çocuklara cinsel istismarda bulunan çocukların ise diğer gruba kıyasla arkadaşlık ilişkilerinde daha çekingen, daha geri planda ve daha yalnız oldukları, (Ueda 2017) ayrıca söz konusu çocukların akran zorbalığı davranışında bulunma öykülerinin de bulunduğu görülmektedir (Hunter ve ark. 2003, Hendriks ve Bijleveld 2004, Gunby ve Woodhams 2010).

CSYÇ'lerin yetişkin bireyler olarak cinsel suçu mükerrer bir şekilde sergilemeye devam etmesi cinsel suçların yapısından kaynaklandığı düşünülmektedir. Suçun tekerrürü, failin/sanığın aynı suçu ya da aynı gruba ait suç davranışını ceza infaz yaşantısına girmeden ya da infaz tamamlandıktan sonra tekrarlaması olarak tanımlanmaktadır. Cinsel suçlarda ise failin/sanığın özellikleri yani tipolojisi ve o zamana kadar geliştirmiş olduğu risk faktörleri suçun tekerrürü adına bir zemin oluşturmaktadır. Suçun tekerrürü baz alındığında ise cinsel eylem failleri üzerinde yapılan incelemeler sonucu kanıta dayalı birçok risk faktörü belirlenmiştir (Mann ve ark. 2010).

Cinsel eylem faillerinin/sanıklarının ya da cinsel istismarcıların, diğer suçluların aksine daha az antisosyal davranış örüntülerine sahip olduğu görülmüştür (Langevin ve Curnoe 2014). Cinsel suç içeren eylemler, toplum düzenini zedeleyebilecek düşünce ve davranışlar bakımından suç olarak nitelendirilmektedir. Cinsellikle ilgili yoğun uğraşlar, psikolojik risk faktörlerinden biri olarak kabul edilmektedir. Cinsellik, bireyin kendini tanımlaması veya zorlanma durumlarıyla karşılaştığında bireyin yanlış bir şekilde geliştirdiği kendi kendini tedavi yöntemi olarak kullanılabilmektedir. Cinsel suç faili olan bireyler için ise cinsel uğraşlar romantik ilişkilerden öte saplantılı bir boyutta olabilmektedir. Yoğun cinsel uğraşları olan failler için cinsellik çoğunlukla tatmin edici olmadığından haz arayışını sürdürebilmektedirler. Bu durum psikiyatrik bağlamda parafili olarak açıklanabilmektedir (Långström ve ark. 2004). Çoklu parafililer, iki ya da daha fazla olağandışı ve sosyal anlamda çarpık; kişilere, nesnelere veya aktivitelere yönelik cinsel ilgi olarak tanımlanmaktadır (Laws ve O’Donohue 2008). Cinsel suç failleri arasında özellikle cinsel suçu tekrarlayan bir biçimde işlemeleri bakımından ise en yaygın görülen parafililer; pedofili, göstermecilik, gözetlemecilik olarak saptanmıştır (Kaseweter ve ark. 2016). Hanson ve Morton-Bourgon'un (2004) risk faktörleri üzerine yapmış oldukları metaanaliz çalışmasına göre cinsel eylemin gelişmesine sebep olan ve olağan suçun tekerrürünü yordayıcı bir başka risk faktörü ise failin ergenlik öncesi ya da ön-ergenlik döneminde olan çocukları cinsel anlamda tercih etmeleridir. Parafililerden farklı olarak bu tercihin, bireylerin içinde yaşadıkları sosyal çevreyi yanlış algılamalarından kaynaklı olabileceği düşünülmektedir.

Psikoloji literatürüne göre bahane üretmek, bireylerin olumsuz atıfta bulundukları düşünce ve davranışlarını rasyonelize etme anlamı taşımaktadır (D’Urso ve ark. 2019). Mann ve Shingler (2006) ise cinsel suçluların benlik saygıları ve benlik imgeleri adına ödün vermemek için bu yola başvurduklarını iddia etmektedirler. Saldırganlığı destekleyici tutumlara sahip bireylerde, suçu meşrulaştırmak ve suça bir bahane üretmek cinsel saldırı ve cinsel istismar olgularında bir risk faktörü olarak öngörülmektedir. Cinsel istismar faillerine göre, çocuğun da bu cinsel eylemden keyif aldığı, yetişkin ve çocuk arasında olan cinselliğin zararlı olmayacağı ya da çocukların da cinsel anlamda kabullenici oldukları düşünceleri bu bağlamda saldırganlığı destekleyici tutumlara girmektedir (Szlachcic ve ark. 2015). Bunun yanı sira yapılan iki farklı metaanaliz çalışmasına göre, yetişkin partnerlerle romantik ilişkilerin azlığı ya da hiç olmaması, cinsel nitelikli suçun oluşumu ve tekerrürü açısından istatistiksel olarak anlamlı bir risk faktörü olduğu tespit edilmiştir (Hanson ve Bussière 1998, Hanson ve Morton-Bourgon 2004). Dolayısıyla romantik ilişki öyküsünün eksikliği aynı zamanda atipik cinsel uğraşların da bir göstergesi olabilmektedir (Blanchard ve Bogaert 1997).

Mann ve ark.'na (2010) göre, denetimsiz ve dürtüsel mizaca sahip bireylerde suçun tekerrürü daha yüksek düzeyde görülmektedir. Düşük öz denetim, sürekli iş ve yerleşim yeri değiştirme, günlük rutinlerdeki tutarsızlık, sorumluluk alabilecek kararlar verememek ve gerçekçi olmayan uzun vadeli hedefler yüksek riskli cinsel suçlu profilini yordamaktadır. Bununla birlikte karar verme sürecindeki çarpıklıklar da araştırmacıların dikkatini çekmektedir. Yetersiz problem çözme becerileri ve başa çıkma tutumlarındaki çarpıklıklar, suç içeren davranışların oluşumunda önemli bir yere sahiptir. Buna göre, düşük problem çözme becerileri, günlük hayattaki problemlere yönelik etkili çözümler üretmedeki bilişsel yetersizliği de temsil etmektedir. Failler, karşılaştıkları problemlerden kaçınabilmekte veya etkisiz problem çözme metotları geliştirebilmektedir (Mann ve ark. 2010).

Cinsel suçun tekerrürünü oluşturan bir başka unsur olan savunma mekanizmaları, bireylerin karşılaştıkları stres unsurlarına karşı benliklerini korumak adına verdikleri tepkiler olarak nitelendirilmektedir. Faillere yapılan risk değerlendirmelerinde ise, işlevsiz savunma mekanizmalarının sıklıkla kullanıldığı saptanmıştır. Genellikle cinsel suç faillerinin, kendilerini zorlayan stres durumları ile karşılaştıklarında cinsel tepkiler veya dışa vurumsal davranışlarla karşılık verdikleri belirlenmiştir. Buna göre öfke, kaygı, reddedilme ve küçük düşürülmeye karşı failler tarafından cinsel saldırganlığın kullanılması savunma 
mekanizmalarındaki işlevsizliği işaret etmektedir. Cinselliğin bir savunma mekanizması olarak kullanıldığı durumlarda, failin temel motivasyonu olumsuz duygular yaratan yaşam zorluklarına karşı cinselliğin bir çözüm yolu olarak kullanılması üzerinedir (Cortoni ve Marshall 2001). Cinsel içerikli davranışın sapkın veya normal olması bir yana genellikle cinsellik, duygusal bağın önemsenmediği, sürekli partner değiştirilen bir ilişki biçiminde kendini göstermektedir. Cinselliği bir savunma mekanizması olarak kullanan cinsel suç failleri, genellikle stres durumlarında cinsel fantazilerinin ve mastürbasyon sıklıklarının arttığını ifade etmektedirler. Bu açıdan cinsel istismarcı ve cinsel saldırı failleri incelendiğinde olumsuz duygulanım ile cinsel eylemler arasında yüksek bir ilişki tespit edilmiştir (McKibben ve ark. 1994, Whitaker ve ark. 2008).

Çocukluk döneminde mevcut olan karşıt olma karşı gelme bozukluğu, davranım bozukluğu ve zıtlaşma bozukluğu gibi antisosyal davranış örüntülerine zemin oluşturabilen bozuklukların varlığı, yetişkinlik döneminde de otoriteye karşı gelici davranışlarla karakterize antisosyal kişilik bozukluğunu oluşturabilmektedir. Bridgewater çalışması verilerine göre, kurallara ve denetime karşı gelici davranışlar cinsel suçu ve cinsel suçun on yıllık takip sırasında tekerrürünü yordayıcı faktörlerden biri olduğu saptanmıştır (Knight ve Thornton 2007).

\section{Sonuç}

$\mathrm{Bu}$ çalışmada çocuk cinsel suçluların/istirmacıların ve saldırganların çeşitli risk faktörlerine göre yapılan gruplandırmalarıve sistematik kategorizasyonlarıliteratürtemelli bir şekilde incelenmiştir. Günümüzde iletişim ağının gelişmesi ve yaygınlaşması ile cinsel anlamda saldırgan davranışların ve bu davranışlara yönelik tepkilerin eşgüdümlü olarak arttığı tespit edilmiştir. Adli bilimlerin bir dalı olan suç ve davranış bilimleri, suçun önlenmesi amacıyla ve bireylerin hakları gözetilerek uygun penolojik yaklaşımlar geliştirmek üzerinde yoğunlaşmaktadır. Cinsel istismar ve cinsel saldırı olgularında failin davranışı hangi erekle gerçekleştirdiğinin ve bu davranışın tekrarlı olup olmadığının tespiti hem birey hem de toplum açısından koruyucuönleyici bir girişim olmaktadır. Ayrıca bireylerin gelişimsel öykülerinin incelenmesi ve olası suç öykülerinin ya da antisosyal davranış belirteçlerinin tespit edilmesi de suçun önlenmesi adına gerekmektedir. Cinsel istismar ve/veya cinsel saldırı faillerinin birbirinden farklı risk faktörleri, gelişim öyküleri ve suçu işleyiş biçimleri ile suçun tekerrürü açısından büyük önem taşıyan fail tipolojilerinin belirlenmesi; hem mağdurun yıpranmasının (tekrar tekrar travmatize olmasının) önüne geçilebilecek yargı sürecinin kısalmasını hem de failin uygun yaptırımlarla cezalandırılmasını sağlayacaktır.

Yazarların Katkıları: Yazarlar çalışmaya önemli bir bilimsel katkı sağladıklarını ve makalenin hazırlanmasında veya gözden geçirilmesinde yardımcı olduğunu kabul etmiştir.

Danışman Değerlendirmesi: Dış bağımsız.

Çıkar Çatışması: Yazarlar çıkar çatışması bildirmemiştir.

Finansal Destek: Yazarlar bu çalışma için finansal destek almadığını beyan etmiştir.
Authors Contributions: The authors attest that she has made an important scientific contribution to the study and has assisted with the drafting or revising of the manuscript.

Peer-review: Externally peer-reviewed.

Conflict of Interest: No conflict of interest was declared by the authors. Financial Disclosure: The authors declared that this study has received no financial support.

\section{Kaynaklar}

Abbey A, Jacques-Tiura AJ, LeBreton JM (2011) Risk factors for sexual aggression in young men: An expansion of the confluence model. Aggress Behav, 37:450-464.

Adshead G, Brodrick P, Preston J (2012) Personality disorder in adolescence. Adv Psychiatr Treat, 18:109-118.

Aebi M, Vogt G, Plattner B (2012) Steinhausen HC, Bessler C, Offender types and criminality dimensions in male juveniles convicted of sexual offenses. Sex Abuse, 24(3):265-288

American Psychiatric Association (2013) Diagnostic and Statistical Manual of Mental Disorders, 5th edition. Washington DC, American Psychiatric Association.

Blanchard R, Bogaert AF (1997) Additive effects of older brothers and homosexual brothers in the prediction of marriage and cohabitation. Behav Genet, 27:45-54.

Burt MR, Estep RE (1981) Who is a victim? definitional problems in sexual victimization. Victimology, 6:15-28.

Butler S, Seto M (2002) Distinguishing two types of adolescent sex offenders. J Am Acad Child Adolesc Psychiatry, 41:83-90.

Carr CP, Martins CM, Stingel AM, Maria A, Braga LV (2013) Francisco M. The role of early life stress in adult psychiatric disorders: A systematic review according to childhood trauma subtypes. J Nerv Ment Dis, 201:1007-1020.

Colins O, Vermeiren R, Schuyten G, Broekaert E (2009) Psychiatric disorders in property, violent and versatile offending in detained male adolescents. Am J Orthopsychiatry, 79:31-38.

Comeau N, Stewart SH, Loba P (2001) The relations of trait anxiety, anxiety sensitivity, and sensation seeking to adolescents' motivations for alcohol, cigarette, and marijuana use. Addict Behav, 26:803-825.

Connell RW (2000) The Men and the Boys. Los Angeles, University of California Press

Cortoni F, Marshall WL (2001) Sex as a coping strategy and its relationship to juvenile sexual history and intimacy in sexual offenders. Sex Abuse, 13:27-44.

D’Urso G, Petruccelli I, Costantino V, Zappulla C, Pace U (2019) The role of moral disengagement and cognitive distortions toward children among sex offenders. Psychiatry, Psychology and Law, 26:414-422.

Easton SD, Saltzman LY, Willis DG (2013) Would you tell under circumstances like that? Barriers to disclosure of child sexual abuse for men. Psychol Men Masc, 15:460-469.

Fanniff AM, Becker JV (2006) Specialized assessment and treatment of adolescent sex offenders. Aggress Violent Behav, 11:265-282.

Farmer M, McAlinden AM, Maruna S (2016) Sex offending and situational motivation: Findings from a qualitative analysis of desistance from sexual offending. Int J Offender Ther Comp Criminol, 60:1756-1775.

Fazel S, Doll H, Langström N (2008) Mental disorders among adolescents in juvenile detention and correctional facilities: A systematic review and metaregression analyses of 25 surveys. J Am Acad Child Adolesc Psychiatry, 47:1010-1019.

Fe Koch K (2004) Child sexual abuse prevention: feminism, masculinity, and preventing the socialization of future offenders. Master of Arts. Toronto, University of Toronto. 
Finkelhor D (2009) The prevention of childhood sexual abuse. Future Child, 19:169-194.

Ford ME, Linney JA (1995) Comparative analysis of juvenile sexual offenders, violent non-sexual offenders, and status offenders. J Interpers Violence, 10:56-70.

Gannon TA, Terriere R, Leader T (2012) Ward and Siegert's pathways model of child sexual offending: A cluster analysis evaluation. Psychol Crime Law, 18:129-153.

Glowacz F, Born M (2013) Do adolescent child abusers, peer abusers, and non-sex offenders have different personality profiles? Eur Child Adolesc Psychiatry, 22:117-125.

Gunby C, Woodhams J (2010) Sexually deviant juveniles: Comparisons between the offender and offence characteristics of "child abusers" and "peer abusers. Psychol Crime Law, 16:47-64.

Hanson RK, Bussière MT (1998) Predicting relapse: A meta-analysis of sexual offender recidivism studies. J Consult Clin Psychol, 66:348-362.

Hanson RK, Morton-Bourgon KE (2004) Predictors of Sexual Recidivism: An Updated Meta-Analysis. Ottawa, Public Works and Government Services Canada

Harkins L, Beech AR (2007) A review of the factors that can influence the effectivenessof sexual offender treatment: Risk, need, responsivity, and process issues. Aggress Violent Behav, 12:615-627.

Hendriks J, Bijleveld CCJH (2004). Juvenile sexual delinquents: Contrasting child abusers with peer abusers. Crim Behav Ment Health, 14:238-250.

Howell JC, Kriberg B, Jones M (1995) Trends in juvenile crime and youth violence. In A Sourcebook: Serious, Violent, \& Chronic Juvenile Offending (Eds JC Howell, B Krisberg, JD Hawkins, JJ Wilson). California, Sage.

Hsu LKG, Starzynski J (1990) Adolescent rapists and adolescent child sexual assaulters. Int J Offend Ther Comp Criminol, 34(1):23-30.

Hunter JA (2017) The sexual crimes of juveniles. Practical aspects of rape investigation: A multidisciplinary approach 5th Edition (Eds RR Hazelwood, AW Burgess). New York, CRC Press.

Hunter JA, Figueredo AJ, Malamuth NM, Becker JV (2003) Juvenile sex offenders: Toward the development of a typology. Sex Abuse, 15:27-48.

Joyal CC, Carpentier J, Martin C (2016) Discriminant factors for adolescent sexual offending: On the usefulness of considering both victim age and sibling incest. Child Abuse Negl, 54:10-22.

Kara B, Biçer Ü, Gökalp A (2004) Çocuk istismarı. Çocuk Hastalıkları ve Sağlığı Dergisi, 47:140-151.

Kaseweter K, Woodworth M, Logan M, Freimuth T (2016) High-risk sexual offenders: Towards a new typology. J Crim Justice, 47:123-132.

Keelan CM, Fremouw WJ (2013) Child versus peer/adult offenders: A critical review of the juvenile sex offender literature. Aggress Violent Behav, 18:732-744.

Knight RA, Thornton D (2007) Evaluating and Improving Risk Assessment Schemes for Sexual Recidivism: A Long-Term Follow-Up of Convicted Sexual Offenders. Document No. 217618, Washington, U.S. Department of Justice.

Kurtay D, Özkök S, Barlık Y, Kurtay A, Akman E (2004) Çocuk İhmal ve İstismarına Multidisipliner Yaklaşım. Aydın, T.C. Başbakanlık Sosyal Hizmetler ve Çocuk Esirgeme Kurumu.

Langevin R, Curnoe S (2014) Psychological profile of sex offenders using weapons in their crimes. J Sex Aggress, 20:55-68.

Långström N, Sjöstedt G, Grann M (2004) Psychiatric disorders and recidivism among sexual offenders. Sex Abuse, 16:139-150.

Laws DR, O’Donohue WT (2008) Sexual Deviance: Theory, Assessment, and Treatment. 2nd edition. New York, Guilford Press.

LeBlanc M, Loeber R (1998) Developmental criminology updated. J Crime Justice, 23:115-198.
Leroux EJ, Pullman LE, Motayne G (2016) Victim age and the generalist versus specialist distinction in adolescent sexual offending. Sex Abuse, 28:79-95

Loeber R, Farrington DP, Stouthamer-Loeber M, Moffitt TE, Caspi A, Lynam D (2001) Male mental health problems, psychopathy, and personality traits: Key findings from the first 14 years of the Pittsburgh Youth Study. Clin Child Fam Psychol Rev, 4:273-297.

Loeber R, Hay DF (1994) Developmental approaches to aggression and conduct problems. In Development through Life: A Handbook for Clinicians (Eds M Rutter, DF Hay). London, Blackwell Scientific Publications.

Loeber R, Wung P, Keenan K, Giroux B, Southamer-Loeber M, Van Kammen WB et al. (1993). Developmental pathways in disruptive child behavior. Dev Psychopathol, 5:103-133.

MacMillan HL, Tanaka M, Duku E, Vaillancourt T, Boyle MH (2013) Child physical and sexual abuse in a community sample of young adults: Results from the Ontario Child Health Study. Child Abuse Negl, 37:14-21.

Mann RE, Hanson RK, Thornton D (2010) Assessing risk for sexual recidivism: Some proposals on the nature of psychologically meaningful risk factors. Sex Abuse 22:191-217.

Mann RE, Shingler J (2006) Schema-driven cognition in sexual offenders: Theory, assessment and treatment. In Sexual Offender Treatment: Controversial Issues,(Eds WL Marshall, YM Fernandez, LE Marshall, GA Serran):173-185. New York, Wiley.

Martínez-Catena A, Redondo S, Frerich N, Beech AR (2017) A dynamic risk factors-based typology of sexual offenders. Int J Offender Ther Comp Criminol, 61(14):1623-1647.

McCuish EC, Lussier P, Corrado RR (2015) Examining antisocial behavioral antecedents of juvenile sexual offenders and juvenile non-sexual offenders. Sex Abuse, 27(4):414-438.

McKibben A, Proulx J, Lusignan R (1994) Relationships between conflict, affect and deviant sexual behaviors in rapists and pedophiles. Behav Res Ther, 32:571-575.

Moffitt TE (1993) Life-course-persistent and adolescent-limited antisocial behavior: A developmental taxonomy. Psychol Rev, 100:674-701.

Nurcombe B (2000) Child sexual abuse I: Psychopathology. Aust NZ J Psychiatry, 34:85-91.

Polat O (2000) Adli Trp. İstanbul, Der Yayınları.

Polat O (2017) Tüm Boyutlarıyla Çocuk İstismarı-I, 2. Baskı, Ankara, Seçkin Yayincilik.

Reitzel LR, Carbonell JL (2006) The effectiveness of sexual offender treatment for Juveniles as measured by recidivism: A meta-analysis. Sex Abuse, 18:401-421.

Seto MC, Lalumière ML (2010) What is so special about male adolescent sexual offending? A review and test of explanations through meta-analysis. Psychol Bull, 136:526-575.

Spertus KW, Yehuda R, Wong CM, Halligan S, Seremetis SV (2003) Childhood emotional abuse and neglect as predictors of psychological and physical symptoms in women presenting to a primary care practice. Child Abuse Negl, 27:1247-1258.

Stewart AJ, Steiman M, Cauce AM, Cochran BN, Whitbeck LB, Hoyt DR (2004) Victimization and posttraumatic stress disorder among homeless adolescents. J Am Acad Child Adolesc Psychiatry, 43:325-331.

Szlachcic R, Fox S, Conway C, Lord A, Christie A (2015) The relationship between schemas and offence supportive attitudes in mentally disordered sexual offenders. J Sex Aggress, 21:318-336.

Taner Y, Bahar G (2004) Çocuk istismarı ve ihmali, psikiatrik yönleri. Hacettepe Tip Dergisi, 35:82-85.

TCK (Türk Ceza Kanunu) (2004). Ankara. Available from https://www. mevzuat.gov.tr/MevzuatMetin/1.5.5237.pdf. (Accessed 18.01.2020). 
Ueda M (2017) Developmental risk factors of juvenile sex offenders by victim age: An implication for specialized treatment programs. Aggress Violent Behav, 37:122-128.

van der Put CE, Asscher JJ (2015) Protective factors in male adolescents with a history of sexual and/or violent offending: A comparison between three subgroups. Sex Abuse, 27:109-126.

van Wijk A, Mali S, Bullens R (2007) Juvenile sex-only and sex-plus offenders: An exploratory study on criminal profiles. Int J Offender Ther Comp Criminol, 51:407-419.

van Wijk A, van Horn J, Bullens R, Bijleveld C. Doreleijers TA (2005) Juvenile sex offenders: A group on its own? Int J Offender Ther Comp Criminol, 49:25-36.

van Wijk A, Vermeiren R, Loeber R, 't Hart-Kerkhoffs L, Doreleijers T et al. (2006) Juvenile sex offenders compared to non-sex offenders: A review of the literature 1995-2005. Trauma Violence Abuse, 7:227-243.

Vess J, Skelton A (2010) Sexual and violent recidivism by offender type and actuarial risk: Reoffending rates for rapists, child molesters and mixedvictim offenders. Psychol Crime Law, 16:541-554.
Whitaker DJ, Le B, Hanso KR, Baker CK, Baker CK, McMahon PM, Ryan G et al. (2008) Risk factors for the perpetration of child sexual abuse: A review and metaanalysis. Child Abuse Negl, 32:529-548.

Woodworth M, Freimuth T, Hutton EL, Carpentera T, Agar AD, Logan M (2013) High-risk sexual offenders: An examination of sexual fantasy, sexual paraphilia, psychopathy, and offence characteristics. Int J Law Psychiatry, 36(2):144-156.

WHO (2002) World Report on Violence and Health- Sexual Violence. Geneva, World Health Organization.

WHO (2011) Violence Against Women - Intimate Partner And Sexual Violence Against Women. Geneva, World Health Organization.

Worling JR, Curwen T (2000) Adolescent sexual offender recidivism: Success of specialized treatment and implications for risk prediction. Child Abuse Negl, 24:965-982. 